УДК 378.091:159.95]:373.3

DOI https://doi.org/10.32782/apv/2021.5.17

\title{
Марія ПОЧИНКОВА
}

доктор педагогічних наук, професор кафедри філологічних дисииплін, ДЗ «Луганський національний університет імені Тараса Шевченка», пл. Гоголя, 1, м. Старобільськ, Луганська область, Україна, 92703

ORCID: 0000-0002-1383-7470

Бібліографічний опис статті: Починкова, М. (2021). Ціле-результативний компонент формування критичного мислення майбутніх учителів початкової школи у процесі професійної підготовки. Acta Paedagogica Volynienses, 5, 112-117, doi: https://doi.org/10.32782/apv/2021.5.17

\section{ЦІЛЕ-РЕЗУЛЬТАТИВНИЙ КОМПОНЕНТ ФОРМУВАННЯ КРИТИЧНОГО МИСЛЕННЯ МАЙБУТНІХ УЧИТЕЛІВ ПОЧАТКОВОЇ ШКОЛИ У ПРОЦЕСІ ПРОФЕСІЙНОЇ ПІДГОТОВКИ}

У статті на підставі системного підходу розкрито один із компонентів системи формування критичного мислення майбутніх учителів початкової школи у процесі професійної підготовки. До складників цієї системи також належать иіле-результативний, теоретико-методологічний, суб 'єкт-суб' єктний, змістово-технологічний, діагностичний компоненти. Зміст иіле-результативного компонента полягає у визначенні провідної мети, яка є системоутворювальним чинником, реалізується на трьох рівнях (глобальному, локальному, оперативному) та знаходить своє втілення в конкретному результаті - підвищенні рівня сформованості критичного мислення майбутніх учителів початкової школи. Докладно розкрито кожен із трьох рівнів змісту иіле-результативного компонента. Так, на глобальному рівні відбувається педагогічна інтерпретація суспільно-державного замовлення в побудові моделі формування критичного мислення майбутніх учителів початкової школи в процесі професійної підготовки. Глобальний рівень репрезентовано державними, суспільними та оперативними иілями, які трунтуються на найсучасніших нормативно-правових документах України та концептуальних положеннях. На локальному рівні формування критичного мислення майбутніх учителів початкової школи стає одним зі складників ініціативних ичілей на всіх предметах професійного спрямування в процесі навчання в закладі вищої освіти. На оперативному рівні мета полягає у формуванні иілей відповідно до кожного окремого виду діяльності (навчальної, квазіпрофесійної, навчально-професійної) та, відповідно, до вивчення навчальних предметів професійного спрямування, які відповідно до навчальних планів належать до циклу професійної підготовки. Реалізація иілей на оперативному рівні здійснюється з опорою на оновлену таксономію изілей Блума-Андерсон. 3 визначення иілей логічно випливають очікувані результати.

Ключові слова: критичне мислення, иільовий компонент, формування критичного мислення, майбутні учителі початкової школи, професійна підготовка.

\section{Mariia POCHYNKOVA}

Doctor of Pedagogical Sciences, Professor at the Department of Philological Disciplines, State Institution Luhansk Taras Shevchenko National University, Gogol Square, 1, Starobilsk, Luhansk Region, 92703

ORCID: 0000-0002-1383-7470

To cite this article: Pochynkova, M. (2021). Tsile-rezultatyvnyi komponent formuvannia krytychnoho myslennia maibutnikh uchyteliv pochatkovoi shkoly u protsesi profesiinoi pidhotovky [Aim and resultative component of critical thinking forming of future teachers of primary school in the process of professional training]. Acta Paedagogica Volynienses, 5, 112-117, doi: https://doi.org/10.32782/apv/2021.5.17

\section{AIM AND RESULTATIVE COMPONENT OF CRITICAL THINKING FORMING OF FUTURE TEACHERS OF PRIMARY SCHOOL IN THE PROCESS OF PROFESSIONAL TRAINING}

One of components of the system of critical thinking forming of future teachers of primary school in the process of professional training is exposed in the article on the basis of system approach. Goal and resultative, theoretical and methodological, subject-to-subject, semantical and technological, diagnostic components also belong to 
the constituents of this system. The content of goal and resultative component consists in determination of leading aim that is a systemically important factor and is realized at three levels (global, local, operative) and finds its embodiment in a concrete result - increase of level of critical thinking formedness of future teachers of primary school. Each of three levels of content of goal and resultative component is thoroughly exposed at each level. So, at global level there is pedagogical interpretation of publicly-state order in the construction of model of critical thinking forming of future teachers of primary school in the process of professional training. Global level is presented by state, public and operative aims that are based on the most modern normatively-legal documents of Ukraine and conceptual positions. At local level critical thinking forming of future teachers of primary school becomes one of constituents of initiative aims on all subjects of professional direction in the process of studies in establishment of higher education. At operative level an aim consists in forming of aims in accordance with each separate type of activity (educational, quasi-professional, educational and professional) and in accordance with the study of educational subjects of professional direction, that in accordance with curricula belong to the cycle of professional preparation. Realization of aims at operative level comes true with support on the renewed taxonomy of aims of Bloom-Anderson. Expected results come out logically from determination of aims.

Key words: critical thinking, target component, critical thinking forming, future teachers of primary school, professional training.

Актуальність проблеми. Сучасна професійна освіта у ЗВО потребує трансформації та вдосконалення, адже на неї покладена місія підготовки майбутніх фахівців, які будуть розбудовувати нашу державу й виховувати майбутнє покоління. Однією з найактуальніших навичок, необхідних сучасним спеціалістам, є критичне мислення (далі - КМ). Тож професійна підготовка має бути спрямована і на формування цієї навички. Особливо ця проблема торкається підготовки майбутніх учителів початкової школи (далі - МУПШ), бо саме вони будуть готувати наших громадян, чиє вміння критично мислити визначатиме вектор розвитку країни, а формування такого вміння необхідно розпочати 3 модернізації системи професійної підготовки майбутніх учителів початкової школи.

Аналіз останніх досліджень і публікацій. Проблеми формування критичного мислення здобувачів різних освітніх рівнів розглянуто в студіях вітчизняних і зарубіжних дослідників (I. Загашев, C. Заїр-Бек, М. Коарін, I. Муштавинська, О. Пометун, С. Терно, О. Тягло та ін.).

Теоретико-методологічні засади технології «Розвиток критичного мислення через читання і письмо» започатковано в роботах зарубіжних учених (К. Мередіт, Дж. Стіл, Ч. Темпл, Д. Халперн).

Концептуальні засади визначення якостей особистості, якій притаманна здатність та вміння критично мислити, представлено в розвідках зарубіжних філософів, педагогів, психологів (Дж. Браус, Д. Вуд, Д. Дьюї, А. Кроуфорд, М. Ліпман, Д. Макінстер, С. Метьюз, Р. Пол, В. Саулія, В. Самнер, Л. Спенсер, П. Фачіоне, Д. Халперн, У. Х'юїт, Дж. Чеффі та ін.).
Незважаючи на значну кількість досліджень, присвячених тим чи тим аспектам формування КМ майбутніх фахівців, зокрема й МУПШ, сьогодні представлені лише поодинокі спроби розробити систему формування КМ МУПШ та їі компоненти.

Мета дослідження - розкрити зміст цілерезультативного компонента як одного зі складників системи формування КМ МУПШ у процесі професійної підготовки.

Виклад основного матеріалу дослідження. Спираючись на концептуальні положення теорії систем (І. Блауберг, В. Садовський, Е. Юдін) та педагогічних систем (Н. Кузьміна), систему формування КМ МУПШ у процесі професійної підготовки визначаємо як цілісну, упорядковану, взаємозумовлену сукупність компонентів (ціле-результативний, теоретико-методологічний, суб'єкт-суб'єктний, змістово-технологічний, діагностичний), що взаємодіють між собою та уможливлюють упровадження технології розвитку критичного мислення як головного чинника його формування в процесі професійної підготовки МУПШ (Починкова, 2021: 21).

Формування КМ МУПШ у процесі професійної підготовки $\epsilon$ педагогічним процесом, який традиційно характеризується цілісністю, системністю, підпорядкованістю єдиній меті. Цілком розділяємо думку Н. Гумерової, яка зазначає, що «в реальному педагогічному процесі мета $є$ визначальним чинником, тим стрижнем, довкола якого педагог об'єднує всі педагогічні засоби в систему, визначаючи місце кожного з них» (Гумерова, 2008: 42). Звичайно, впровадження педагогічного процесу має призвести до певних передбачуваних результатів, які, власне, і визначає поставлена мета. Отже, 
першим компонентом системи, характеристику якого ми докладно розкриємо через ціле-результативний компонент, буде мета та завдання формування КМ МУПШ у процесі професійної підготовки, що підкоряє та об'єднує всі інші компоненти системи.

Натепер у педагогічній науці немає чітко окреслених позицій щодо цілеутворення. Науковці надають визначення дефініцій «ціль (мета)», «освітня мета» та «педагогічна мета». Щодо видів чи рівнів певні напрями в педагогічній науці відсутні. Традиційно визначають тільки триєдину навчальну мету: навчальну, виховну, розвивальну. У світлі нашого дослідження нам імпонує позиція Л. Столяренко щодо виокремлення видів педагогічних цілей. Науковець визначає нормативні державні цілі, суспільні та ініціативні цілі самих педагогів та учнів. За Л. Столяренко, до нормативних державних цілей належать найбільш загальні, що визначаються в урядових документах, державних стандартах освіти. До групи суспільних цілей він відносить і громадські цілі, зокрема й запити роботодавців, які враховує система підготовки майбутніх фахівців. Наступна група ініціативні цілі - реалізується в безпосередніх цілях, які розробляють самі педагоги-практики та їхні учні з урахуванням типу навчального закладу, профілю спеціалізації й навчального предмета, з урахуванням рівня розвитку учнів, підготовленості педагогів (Столяренко, 2015).

Підгрунтям педагогічної системи формування КМ у процесі професійної підготовки МУПШ стало уявлення про ієрархію цілей, що сприяє іiі гнучкості, динамічності й забезпечує «перехід від вимог соціального замовлення на вчителя національної школи до врахування індивідуальних можливостей студентів» (Дубасенюк, 2003: 12). Розроблена модель реалізує процес цілеутворення на трьох рівнях: глобальному, етапному локальному, оперативному. Наголосимо на тому, що цільовий компонент пронизує всі інші компоненти системи. Коротко розглянемо характеристику рівнів і видів цілей.

Представимо ієрархію цілей саме через ці три рівні цілей: глобальний, локальний, оперативний.

На глобальному рівні відбувається педагогічна інтерпретація суспільно-державного замовлення в побудові моделі формування КМ МУПШ у процесі професійної підготовки. Гло- бальний рівень репрезентовано державними, суспільними та оперативними цілями, які грунтуються на таких найсучасніших нормативноправових документах України та концептуальних положеннях, як: Закон України «Про освіту» (2017 p.), Концепція розвитку педагогічної освіти (2018 р.), Постанова Кабінету Міністрів України «Про затвердження Національної рамки кваліфікації» (2011р., 2020 р.), документ «Нова українська школа: основи Стандарту освіти» (2016 р.), Концепція «Нова українська школа» (2016 р.), проєкт Державного стандарту вищої освіти зі спеціальності 013 «Початкова освіта» (2019 р.) та ін. Сформулюємо глобальні цілі, спираючись на ці документи:

- державні освітні цілі. Метою освіти $є$ всебічний розвиток людини як особистості та найвищої цінності суспільства, іiі талантів, інтелектуальних творчих і фізичних здібностей, формування цінностей, необхідних для успішної самореалізації компетентностей, виховання відповідальних громадян, які здатні до свідомого суспільного вибору та спрямування своєї діяльності на користь іншим людям і суспільству, збагачення на цій основі інтелектуального, економічного, творчого культурного потенціалу (Про освіту, 2017); метою вищої освіти $є$ здобуття високого рівня наукових та/ або творчих мистецьких, професійних і загальних компетентностей, необхідних для діяльності за певною спеціальністю чи в певній галузі знань (Про освіту, 2017); виховання громадянина, здатного до самостійного мислення (Про національну доктрину освіти, 2002).

Грунтуючись на компетентнісному підході щодо визначення цілей освіти, в Законі України «Про освіту» та інших документах визначено спільні вміння для всіх компетентностей: читання 3 розумінням, уміння висловлювати власну думку усно й письмово, критичне та системне мислення, здатність логічно обгрунтовувати позицію, творчість, ініціативність, уміння конструктивно керувати емоціями, оцінювати ризики, приймати рішення, розв'язувати проблеми, здатність співпрацювати з іншими людьми (Про освіту, 2017); формування вміння критично та системно мислити, здатність обгрунтовувати свою позицію, оцінювати ризики, приймати рішення, розв'язувати проблеми, здатність співпрацювати 3 іншими людьми (Про освіту, 2017); підготовка студентів 
до професійної діяльності та суспільного життя (Ортинський, 2007); підготовка фахівців, здатних забезпечити перехід від індустріального до інформаційно-технологічного суспільства через новаторство в навчанні, вихованні та науковометодичній роботі (Pro osvitu, 2017) тощо. Отже, державними цілями формування КМ у процесі професійної підготовки МУПШ є підготовка фахівців, які критично та системно мислять;

- суспільні: потреба у фахівцях, здатних до КМ; наявність КМ у здобувачів освіти та фахівців освітньої галузі (Про затвердження Національної рамки кваліфікацій, 2011); МУПШ здатний успішно здійснювати критично мисленнєву діяльність у процесі професійної діяльності.

- ініціативні: орієнтація студентів на морально-етичні цінності людства та усвідомлення цінності знань, пробудження національної та громадської самосвідомості.

На локальному рівні формування КМ МУПШ стає одним зі складників ініціативних цілей на всіх предметах професійного спрямування в процесі навчання у ЗВО. Формування КМ МУПШ на локальному рівні ЗВО відбувається як система за етапами, кожний 3 яких також має власну мету: діагностикопроєктувальний етап - діагностування рівня сформованості КМ. Проєктування системи формування КМ МУПШ у процесі професійної підготовки; організаційно-діяльнісний етап - упровадження системи формування КМ МУПШ у процесі професійної підготовки; контрольно-оцінний етап - оцінка ефективності системи формування КМ МУПШ у процесі професійної підготовки.

На оперативному рівні мета полягає у формуванні цілей відповідно до кожного окремого виду діяльності (навчальної, квазіпрофесійної, навчально-професійної) та, відповідно, до вивчення навчальних предметів професійного спрямування, які згідно 3 навчальними планами належать до циклу професійної підготовки. На цьому етапі можна визначити таку мету: на основі об'єктивного контролю ефективно вдосконалювати освітній процес, спрямований на формування КМ МУПШ у процесі професійної підготовки. Ця мета реалізується в процесі: навчальної діяльності в ії різноманітних академічних формах - аудиторній (лекції, практичні та семінарські заняття) та позааудиторній (самостійна робота), через які стає можливим побудова змісту майбутньої професійної діяльності; квазіпрофесійної діяльності - відтворення елементів праці вчителя початкової школи в умовах 3ВО, проєктування суб'єктних відношень майбутньої професійної діяльності в ігрових формах; навчально-професійної діяльності МУПШ під час різних видів практик, виконання науково-дослідної роботи, написання різних видів робіт у жанрі академічного письма (реферати, курсові роботи).

Вважаємо за доцільне на оперативному рівні розкрити й урахувати мету особистісно зорієнтованої професійної педагогічної освіти, тут ми розділяємо думку Н. Калити, яка визначає цю мету як «підготовку вчителя-професіонала, здатного до самонавчання, самовдосконалення й саморозвитку впродовж життя, який є творчою особистістю, дослідником-пошукувачем, що аналізує, апробує найраціональніші шляхи, умови, методи, засоби, форми високоефективного вирішення конкретних завдань виховання, освіти і навчання, має повагу до особистості учня, розуміс його потреби» (Калита, 2015: 267). Це визначення підкреслює взаємозв'язок усіх рівнів цілей, оскільки враховує цілі і глобального рівня, і локального, і оперативного.

Відзначимо, що реалізація цілей на оперативному рівні здійснюється 3 опорою на оновлену таксономію цілей Блума-Андерсон, яка дозволяє виокремити чотири рівні: елементарний пригадування й усвідомлення, репродуктивний - застосування, конструктивний - аналізування й оцінювання, продуктивно-творчий - створення. Загальновизнаною перевагою таксономії Блума-Андерсон є систематизований підхід до визначення запланованих результатів навчання.

Узагальнюючи сказане вище, можемо поставити перед собою загальну мету впровадження системи формування КМ МУПШ у процесі професійної підготовки - сформувати КМ МУПШ у процесі професійної підготовки, що грунтується на соціальному замовленні: учитель початкової школи, який володіє навичками критичного мислення.

Досягти мети можна тільки під час виконання основних завдань: визначення сучасного рівня сформованості КМ у МУПШ; розроблення системи формування КМ МУПШ у процесі професійної підготовки; підготовки професорсько-викладацького складу до впровадження системи формування КМ МУПШ у про- 
цесі професійної підготовки 3 метою формування КМ; упровадження системи формування КМ МУПШ у процесі професійної підготовки через реалізацію ТРКМ; оцінка ефективності системи формування КМ МУПШ у професійній підготовці загалом.

Отже, ціле-результативний компонент системи формування КМ МУПШ у процесі професійної підготовки з чітко визначеною метою і завданнями є основним орієнтиром для визначення змісту і функцій усіх інших компонентів та елементів системи, визначених нами під час моделювання.

3 визначення цілей логічно випливають очікувані результати, оскільки освітні цілі це свідомо визначені очікувані результати, які прагне досягти певне суспільство, країна, держава за допомогою сформованої системи освіти загалом у теперішньому і найближчому майбутньому; своєю чергою педагогічна мета - це передбачення педагогом і учнем результатів їх взаємодії у форму загальних уявних утворень, відповідно до яких потім співвідносяться всі інші компоненти педагогічного процесу (Столяренко, 2015).

Висновки i перспективи подальших досліджень. Отже, зміст ціле-результативного компонента передбачає визначення результатів нашого дослідження - підвищення сформованості КМ МУПШ у процесі професійної підготовки, а також у визначенні мети й результату дослідження.

Перспективи подальшого дослідження вбачаємо в розкритті змісту всіх компонентів системи формування КМ МУПШ у процесі професійної підготовки.

\section{ЛITEPATУРА:}

1. Гумерова Н.Л. Развитие педагогического целеполагания у учителей общеобразовательных школ: аксиологический подход : дис. .... канд. пед. наук : 13.00.01. Москва, 2008. 217 с.

2. Дубасенюк О.А., Семенюк Т.В., Антонова О.Є. Професійна підготовка майбутнього вчителя до педагогічної діяльності : монографія. Житомир : Житомир. держ. пед. ун-т, 2003. 193 с.

3. Калита Н. Підготовка вчителя початкової школи в контексті сучасних освітніх парадигм. Актуальні питання гуманітарних наук. 2015. Вип. 14. С. 265-269.

4. Ортинський В.Л. Педагогіка вищої школи : навч. посіб. для студ. вищ. навч. закл. Київ : Центр учбової літератури, 2009. $472 \mathrm{c}$.

5. Починкова М.М. Формування критичного мислення майбутніх учителів початкової школи у процесі професійної підготовки : автореф. дис. ... доктора пед. наук : 13.00.04. Старобільськ, 2021. 44 с.

6. Про затвердження Національної рамки кваліфікацій : Постанова Кабінету Міністрів України від 23 листопада 2011 p. № 1341. URL: https://zakon.rada.gov.ua/laws/show/1341-2011-п (дата звернення: 11.03.2020).

7. Про національну доктрину освіти : Указ Президента України від 17.04.02 p. № 347/2002. URL: http://ru.osvita.ua/legislation/other/2827/ (дата звернення: 17.03.2020).

8. Про освіту : Закон України від 05.09.2017 р. № 2145-VIII. Відомості Верховної Ради (ВВР). 2017. № 38-39. Ст. 380. URL: https://zakon.rada.gov.ua/laws/show/2145-19\#Text (дата звернення: 05.04.2019).

9. Столяренко В.Е., Столяренко Л.Д. Психология и педагогика. 4-е изд. Москва : Издательство Юрайт, 2015. $134 \mathrm{c}$.

10. Anderson L., Krathwohl D.R. A Taxonomy for Learning, Teaching and Assessing: A revision of Bloom's Taxonomy of Educational Objectives. New York : Longman, 2001. 336 p.

\section{REFERENCES:}

1. Gumerova, N. L. (2008). Razvitie pedagogicheskogo tselepolaganiya u uchiteley obscheobrazovatelnyih shkol: aksiologicheskiy podhod [The development of pedagogical goal-setting among teachers of secondary schools: an axiological approach] : dis. ... kand. ped. nauk : 13.00.01. Moskva, 2008. 217 p.

2. Dubaseniuk, O. A., Semeniuk, T. V., Antonova, O. Ye. (2003). Profesiina pidhotovka maibutnoho vchytelia do pedahohichnoi diialnosti [Professional training of future teachers for pedagogical activity] : monohrafiia. Zhytomyr : Zhytomyr. derzh. ped. un-t. 193 p.

3. Kalyta, N. (2015). Pidhotovka vchytelia pochatkovoi shkoly v konteksti suchasnykh osvitnikh paradyhm [Primary school teacher training in the context of modern educational paradigms]. Aktualni pytannia humanitranykh nauk. Vyp. 14. P. 265-269.

4. Ortynskyi, V. L. (2009). Pedahohika vyshchoi shkoly [Pedagogy of high school] : navch. posib. dlia stud. vyshch. navch. zakl. Kyiv : Tsentr uchbovoi literatury. 472 p. 
5. Pochynkova, M. M. (2021). Formuvannia krytychnoho myslennia maibutnikh uchyteliv pochatkovoi shkoly u protsesi profesiinoi pidhotovky [Formation of critical thinking of future primary school teachers in the process of professional training] : avtoref. dys. ... doktora ped. nauk : 13.00.04. Starobilsk. $44 \mathrm{~s}$.

6. Pro zatverdzhennia Natsionalnoi ramky kvalifikatsii : Postanova Kabinetu Ministriv Ukrainy vid 23 lystopada 2011 r. № 1341. [On approval of the National Qualifications Framework: Resolution of the Cabinet of Ministers of Ukraine of November 23, 2011 №1341]. Retrieved from: https: //zakon.rada.gov.ua/laws/show/1341-2011-п.

7. Pro natsionalnu doktrynu osvity : Ukaz Prezydenta Ukrainy vid 17.04.02 r. № 347/2002 [On the national doctrine of education: Decree of the President of Ukraine of 17.04.02 № 347/2002]. Retrieved from : http://ru.osvita.ua/legislation/ other/2827/.

8. Pro osvitu : Zakon Ukrainy vid 05.09.2017 r. № 2145-VIII. (2017). [1. On education: Law of Ukraine of 05.09.2017 №2145-VIII]. Vidomosti Verkhovnoi Rady (VVR). № 38-39. St. 380. Retrieved from : https:// zakon.rada.gov.ua/ laws/show/2145-19\#Text.

9. Stolyarenko, V. E., Stolyarenko, L. D. (2015). Psihologiya i pedagogika [Psychology and pedagogy]. 4-e izd. Moskva : Izdatel'stvo YUrajt, $134 \mathrm{s.}$

10. Anderson L., Krathwohl D. R. A Taxonomy for Learning, Teaching and Assessing: A revision of Bloom's Taxonomy of Educational Objectives. New York : Longman, 2001.336 p. 